\title{
Interactions between marine snow and heterotrophic bacteria: aggregate formation and microbial dynamics
}

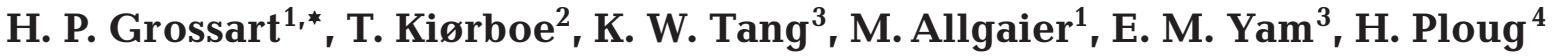 \\ ${ }^{1}$ Leibniz Institute of Freshwater Ecology and Inland Fisheries (IGB), Alte Fischerhuette 2, 16775 Stechlin, Germany \\ ${ }^{2}$ Danish Institute for Fisheries Research, Kavalergården 6, 2920 Charlottenlund, Denmark \\ ${ }^{3}$ Virginia Institute of Marine Science, Gloucester Point, Virginia 23062, USA \\ ${ }^{4}$ Max Planck Institute for Marine Microbiology, Celsiusstrasse 1, 28359 Bremen, Germany
}

\begin{abstract}
Macroscopic aggregates (marine snow) contribute to new production and nutrient dynamics in the upper ocean and vertical fluxes of organic matter to the deep ocean. To test whether microorganisms play a significant role in phytoplankton aggregate formation we studied particle abundance and size as well as abundance, colonization behaviour, and community composition of bacteria during the growth of 2 marine diatoms (Thalassiosira weissflogii and Navicula sp.) under axenic and non-axenic conditions. Community composition of free-living and attached bacteria during phytoplankton growth and aggregation was studied by amplification of 16S rRNA gene fragments and denaturing gradient gel electrophoresis (DGGE). Our results show that the presence of bacteria was a prerequisite for aggregation of $T$. weissflogii but not of Navicula sp. Occurrences of distinct populations of free-living and attached bacteria depended on phytoplankton growth and aggregation dynamics. The community composition of especially attached bacteria significantly differed between the 2 algal cultures. Our study suggests that phytoplankton aggregation and vertical fluxes are closely linked to interactions between the marine phytoplankton and the ambient microbial community.
\end{abstract}

KEY WORDS: Heterotrophic bacteria - Marine diatoms - Aggregates - DGGE - Image analysis . Bacterial behaviour

Resale or republication not permitted without written consent of the publisher

\section{INTRODUCTION}

Fluxes of macroscopic aggregates (marine snow) in the water column not only regulate new production and nutrient dynamics in the upper ocean (Eppley \& Peterson 1979), but also help sequester carbon to the deep ocean. Marine diatoms are common components of marine snow and the vertical particle flux recorded by sediment traps during phytoplankton blooms (Alldredge \& Gotschalk 1990, Waite et al. 2005). Source particles of marine snow interact with their surrounding environment and may change their physical and chemical properties as a result. Many studies have shown that marine snow is densely colonized by microbes (Simon et al. 2002 and references therein), whose activities may degrade and transform these particles (Azam \& Long 2001). High hydrolytic enzyme activities of heterotrophic bacteria may break down marine snow, thereby reducing the vertical flux of organic matter (Smith et al. 1992, Grossart \& Ploug 2001). In contrast, heterotrophic bacteria may increase particle aggregation and stabilize existing aggregates by exopolymer production (Decho 1990, Heissenberger \& Herndl 1994). Based on their behaviour, 3 functional types of bacteria have been described (Rieman et al. 2000, Kirchman 2002, Grossart et al. 2005): (1) bacteria that specialize in colonizing particles ('particle specialists'); (2) free-living bacteria; and (3) bacte- 
ria that can grow in suspension as well as on particles ('generalists'). The predominance of one functional type of bacteria may be indicative of specific interactions between bacterial and algal communities in the course of phytoplankton blooms.

The production of source particles and their subsequent aggregation is under continuous influence of the aforementioned microbial processes in the ocean. In previous studies we have developed an encounter model to predict the rate at which bacteria colonize marine snow particles (Kiørboe et al. 2002). Using agar spheres as model aggregates, we studied bacterial attachment, detachment, growth, cell-cell interactions, and predation in detail (Kiørboe et al. 2001, 2002, 2003, Grossart et al. 2003b). In the present study we examined how the microbial community affect marine snow formation, and in turn how marine snow affects microbial community composition and activities. We tested the following specific hypotheses: (1) aggregate formation is enhanced by the presence of attached bacteria; (2) the ambient bacterial community will shift from one dominated by 'generalists' to 2 distinct populations, one of 'particle specialists' and one of freeliving bacteria, as aggregate abundance increases; (3) the attached bacterial community is specific to the nature of POM (e.g. algal species). Our results show that the presence of bacteria significantly changes phytoplankton aggregation, suggesting that the fate of algal aggregates may hinge on complex mutual effects between the marine phytoplankton and the ambient microbial community.

\section{MATERIALS AND METHODS}

Algal cultures. Two axenic marine diatoms, Thalassiosira weissflogii (CCMP 1053) and Navicula sp. (CCMP 1703), which are common phytoplankton species in the North Atlantic and other temperate waters, were obtained from Provasoli-Guillard National Center for Culture of Marine Phytoplankton (CCMP, ME, USA). The algae were incubated in batch culture in Guillard's f/2 medium at $15^{\circ} \mathrm{C}$ in 11 flasks and illuminated for $24 \mathrm{~h}$ (daylight bulbs).

Aggregation experiment. Exponentially growing diatoms were diluted with raw seawater collected from the Oresund $\left(55^{\circ} 10.05^{\prime} \mathrm{N}, 12^{\circ} 15.04^{\prime} \mathrm{E}\right)$ and incubated in 6 replicates in 11 rolling bottles $(3.2 \mathrm{rpm})$. Initial algal concentrations were 1 to $2 \times 10^{4}$ cells ml ${ }^{-1}$. Controls with axenic diatoms were set up in triplicates. All bottles were sampled daily for aggregate abundance and size, transparent exopolymer particles (TEP), proteinaceous particles (Coomassie Brilliant Blue stainable particles, CSP), and for abundance and community composition of free-living and attached bacteria.
In additional experiments agar spheres were exposed for 1, 2, and $4 \mathrm{~d}$ to ambient water of the respective algal cultures to measure colonization and detachment rates of the bacteria (Kiørboe et al. 2003). The bottles were removed from the rolling device daily to measure particle size spectra. The bottles were submerged in an aquarium, illuminated with a ca. $1 \mathrm{~mm}$ thick sheet of laser light $(650 \mathrm{~nm})$, and viewed from the side with a CCD video camera equipped with a macro lens (105 mm). Aggregates inside each bottle were kept suspended for the duration of their recording (1 to $2 \mathrm{~min})$. We could not avoid sedimentation during recording on Days 5 and 6, when large aggregates occurred in the Navicula sp. bottles. From each sequence, 50 to 100 pictures were captured (every 25th frame) and analyzed using VirtualDub (v1.6.11) and ImageJ (freeware by W. Rasband). The view field was $7.37 \times 5.42 \mathrm{~mm}^{2}$, which is equivalent to a volume of $40 \mathrm{~mm}^{3}$ per frame. Interlacing was 'removed' by VirtualDub. Size calibration for recorded images was done with standard $25 \mu \mathrm{m}$ spheres (Lycopodium spores). Free and cell surface-bound acidic exopolysaccharides (TEP) and proteins (CSP) were detected during incubation by staining with Alcian Blue (Logan et al. 1994) and Coomassie Blue (Long \& Azam 1996), respectively. Aliquots of 1 to $5 \mathrm{ml}$ were filtered onto $0.2 \mu \mathrm{m}$ Nuclepore membranes and stained immediately after filtration. The filters were mounted on frosted slides (Cytoclear $^{\mathrm{TM}}$, Poretics) and examined with light microscopy.

Enumeration of microorganisms. For algae, flagellates and attached bacteria, $5 \mathrm{ml}$ of sample were filtered through black $5.0 \mu \mathrm{m}$ pore size Nuclepore membranes; $1 \mathrm{ml}$ of the filtrate was subsequently filtered through black $0.2 \mu \mathrm{m}$ Nuclepore membranes to collect free-living bacteria. All flagellates directly sitting on the particles were counted as attached flagellates whereas free-living flagellates were unattached. Samples were stained with DAPI (4'6'diamidino-2-phenolindole) or PicoGreen (Molecular Probes) and counted using light and epifluorescence microscopy (Axioplan, Zeiss) at $200 \times$ to $1000 \times$ magnification. At least $10 \mathrm{mi}-$ croscopic fields were counted (Grossart et al. 2003b).

DNA extraction. Particle-bound bacteria and free bacteria were separated by sequential filtration of $50 \mathrm{ml}$ water samples through 5.0 and $0.2 \mu \mathrm{m}$ Nuclepore polycarbonate membranes. Filters were transferred to sterile Eppendorf tubes and kept frozen at $-20^{\circ} \mathrm{C}$ until DNA extraction. Samples on Day 0 were taken after $12 \mathrm{~h}$ of inoculating the axenic algal cultures with natural seawater bacteria. DNA of both free-living and attached bacteria were extracted following the protocol of Zhou et al. (1996), which includes treatment with zirkonium beads and a mixture of $60^{\circ} \mathrm{C}$ hot phenol-chloroform-isoamylalcohol. DNA extraction was checked on an agarose gel (1\%). 
Amplification of 16S rRNA genes and denaturing gradient gel electrophoresis (DGGE). Amplification of 16S rRNA gene fragments and subsequent DGGE analysis was performed according to Brinkhoff \& Muyzer (1997). An equal amount of DNA was loaded in each lane (ca. $500 \mathrm{ng}$ ). DGGE gels were stained with SYBRGold (Molecular Probes) for $45 \mathrm{~min}$ and illuminated on a UV table (Biometra). Cluster analyses of the DGGE banding patterns were performed using the software GelCompare II, Version 3.5 (Applied Maths). The gels were internally standardized by selecting sequenced bands as standard. We applied 5 to $20 \%$ background subtraction depending on the signal-tonoise ratio of the corresponding gel. Patterns were compared curve-based by using Pearson correlation as similarity coefficient and UPGMA (unpaired group method of analysis) to generate the dendrogram. We used the curve-based approach instead of comparing single bands because this analysis is more robust (Ferrari \& Hollibaugh 1999).

\section{RESULTS}

\section{Abundance of algae, bacteria and flagellates}

The development of microorganisms in both Thalassiosira weissflogii and Navicula sp. cultures was very similar (Fig. 1). Both algae showed only a slight initial increase in abundance and then a decrease. Freeliving bacteria increased until Day 4 and declined thereafter. In contrast, attached bacteria increased
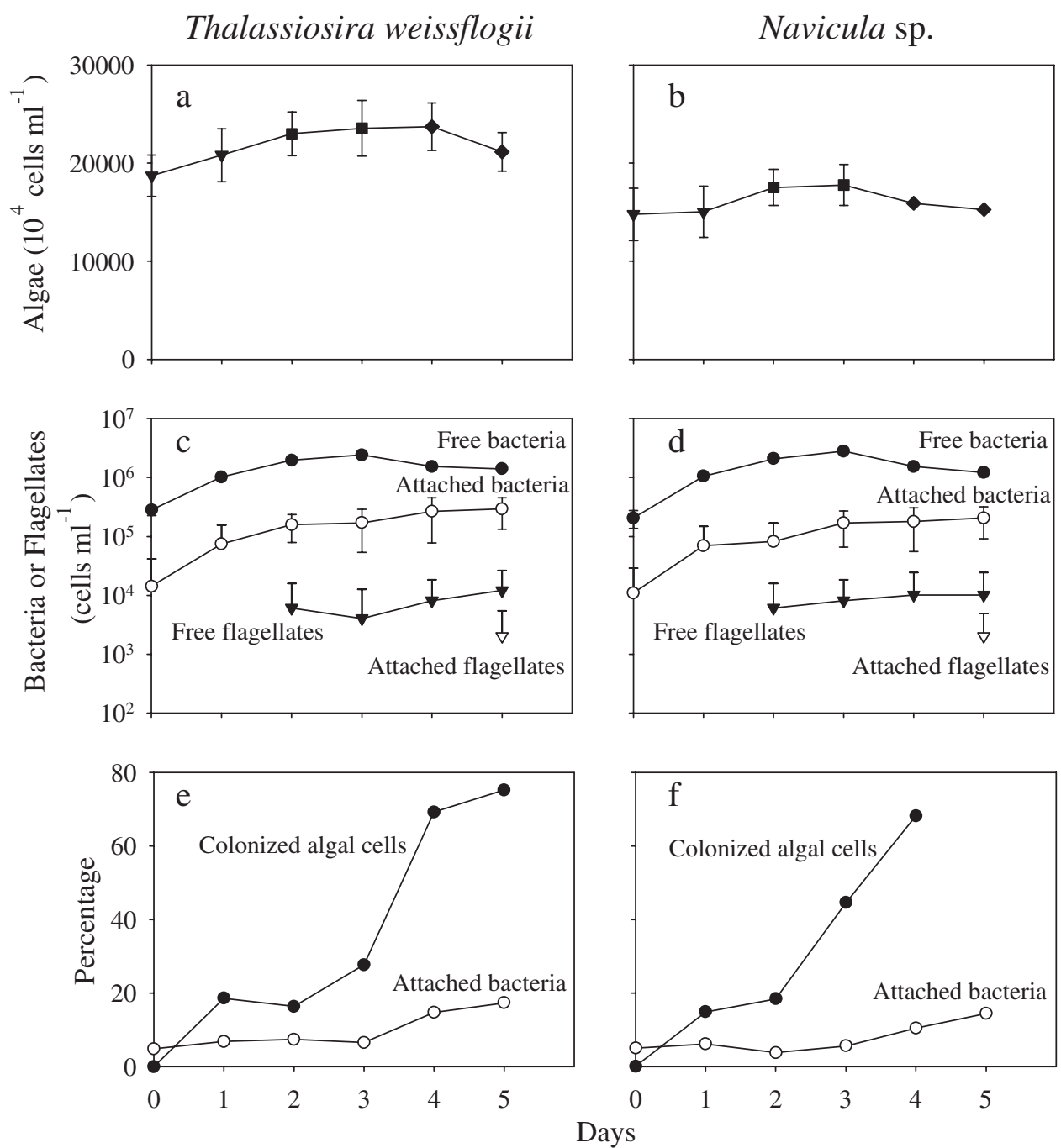

Fig. 1. Diatom culture experiments with $(\mathrm{a}, \mathrm{c}, \mathrm{e})$ non-axenic Thalassiosira weissflogii and $(\mathrm{b}, \mathrm{d}, \mathrm{f})$ Navicula sp. Concentrations of $(a, b)$ algal cells, $(c, d)$ free and attached bacteria and flagellates, and $(e, f)$ percentage of total of algal cells colonized by bacteria and of attached bacteria 

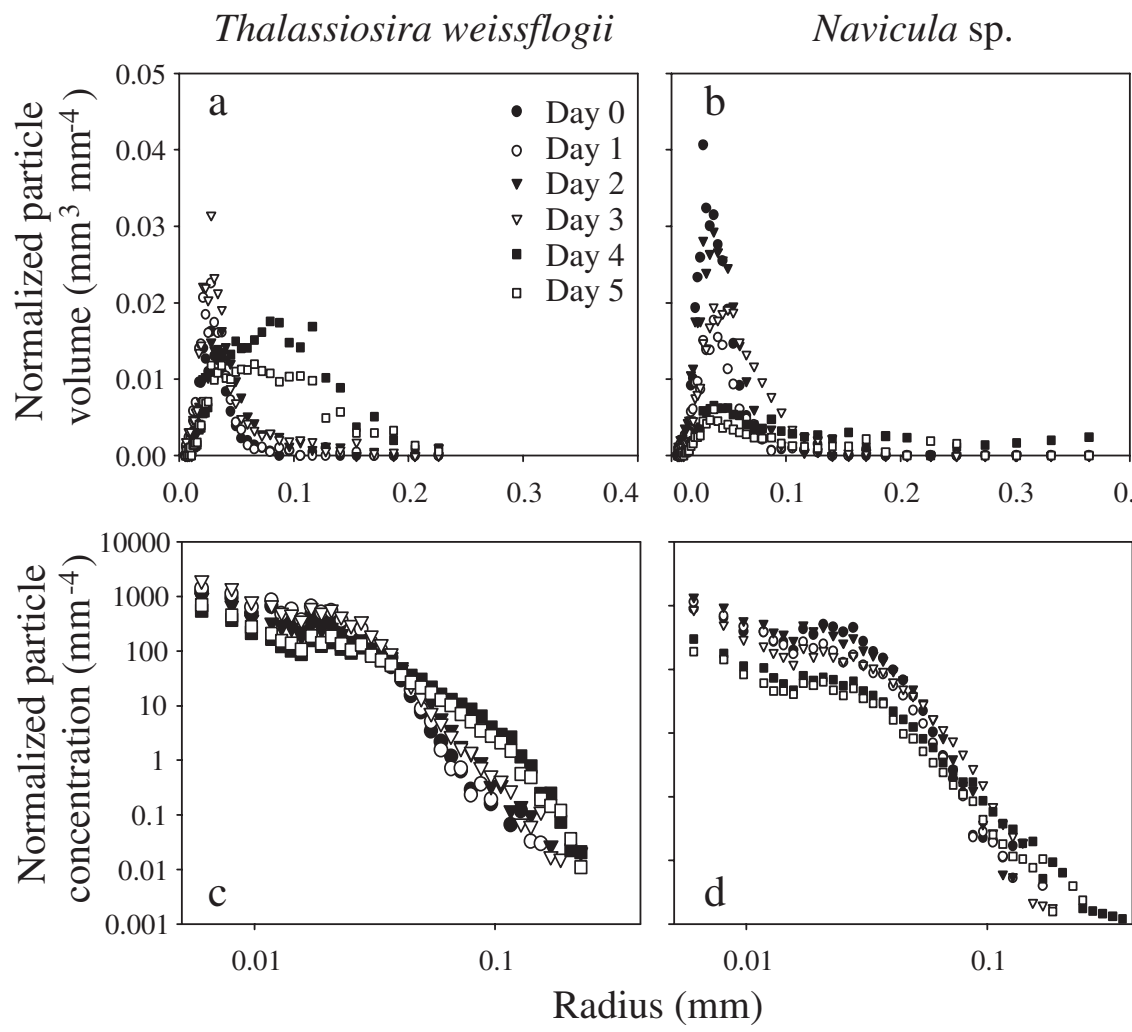

Fig. 2. Diatom culture experiments with $(\mathrm{a}, \mathrm{c})$ non-axenic Thalassiosira weissflogii and (b,d) Navicula sp. (a,b) Particle volume concentration and (c,d) particle concentration (normalized to size classes) as a function of particle size over the $5 \mathrm{~d}$ incubation period

continuously throughout the experiment. Free-living flagellates were detected after $2 \mathrm{~d}$ and steadily increased. Flagellates attached to particles were only detected on the last day of the experiment and were less abundant than the free-living ones.

The fraction of attached bacteria increased throughout the incubation and reached up to 20.9 and $16.9 \%$ of all bacteria in the Thalassiosira weissflogii and Navicula sp. cultures, respectively. The fraction of algal cells colonized by bacteria increased sharply after $3 \mathrm{~d}$ in T. weissflogii and $2 \mathrm{~d}$ in Navicula sp. cultures, during which time aggregates began to form (see Fig. 1). By the end of the experiment, ca. $80 \%$ of T. weissflogii and $70 \%$ of Navicula sp. cells were colonized by bacteria.

\section{Aggregation patterns}

Aggregation of Thalassiosira weissflogii and Navicula sp. was most evident when a substantial fraction of the cells had been colonized by bacteria on Days 4 to 5 . The size of $T$. weissflogii aggregates remained small on Days 0 and 1, and slightly increased on Days 2 and 3. It was different on Days 4 and 5 when large aggregates became evident (Fig. 2). This coincided with a sharp increase in the fraction of $T$. weissflogii cells that were colonized by bacteria (Fig. 1). Temporal development of the size spectra of Navicula sp. aggregates was similar to that of $T$. weissflogii, with a strong decrease in small particles and a corresponding slight increase in large particles through time. Large aggregates were visible in the Navicula sp. culture but were not abundant enough to be detected by our video system. Epifluorescence microscopy revealed that microcolonies of bacteria appeared to glue individual algal cells together to form aggregates. In contrast, axenic cultures of $T$. weissflogii did not aggregate even after $14 \mathrm{~d}$ of incubation. Aggregation of axenic cultures of Navicula sp. did not differ greatly from that of non-axenic cultures and showed increasing numbers and sizes of aggregates throughout the incubation (data not shown). Aggregates of axenic Navicula sp. did not disintegrate with vigorous shaking of the bottles, indicating that the algae were themselves highly sticky. No significant amounts of free TEP or CSP were observed and the aggregates were only slightly stained by the respective histological dyes.

\section{Bacterial community composition}

Except for the Thalassiosira weissflogii culture on Day 0 , the free-living and attached bacterial communities were clearly different (Fig. 3). Banding patterns of attached bacteria also revealed significant differences between the 2 algal cultures. Throughout the incubation bacterial communities on both kinds of particles became increasingly complex and different from those in the ambient water, indicating the development of highly specialised populations of attached bacteria on the respective aggregates. In contrast, temporal variations in community structure of free-living bacteria in both algal cultures were much smaller. Differences in community composition of free bacteria between the 2 algal cultures, however, increased on Days 3 to 5 when the number of phytoplankton aggregates and the fraction of colonized algal cells rapidly increased. 


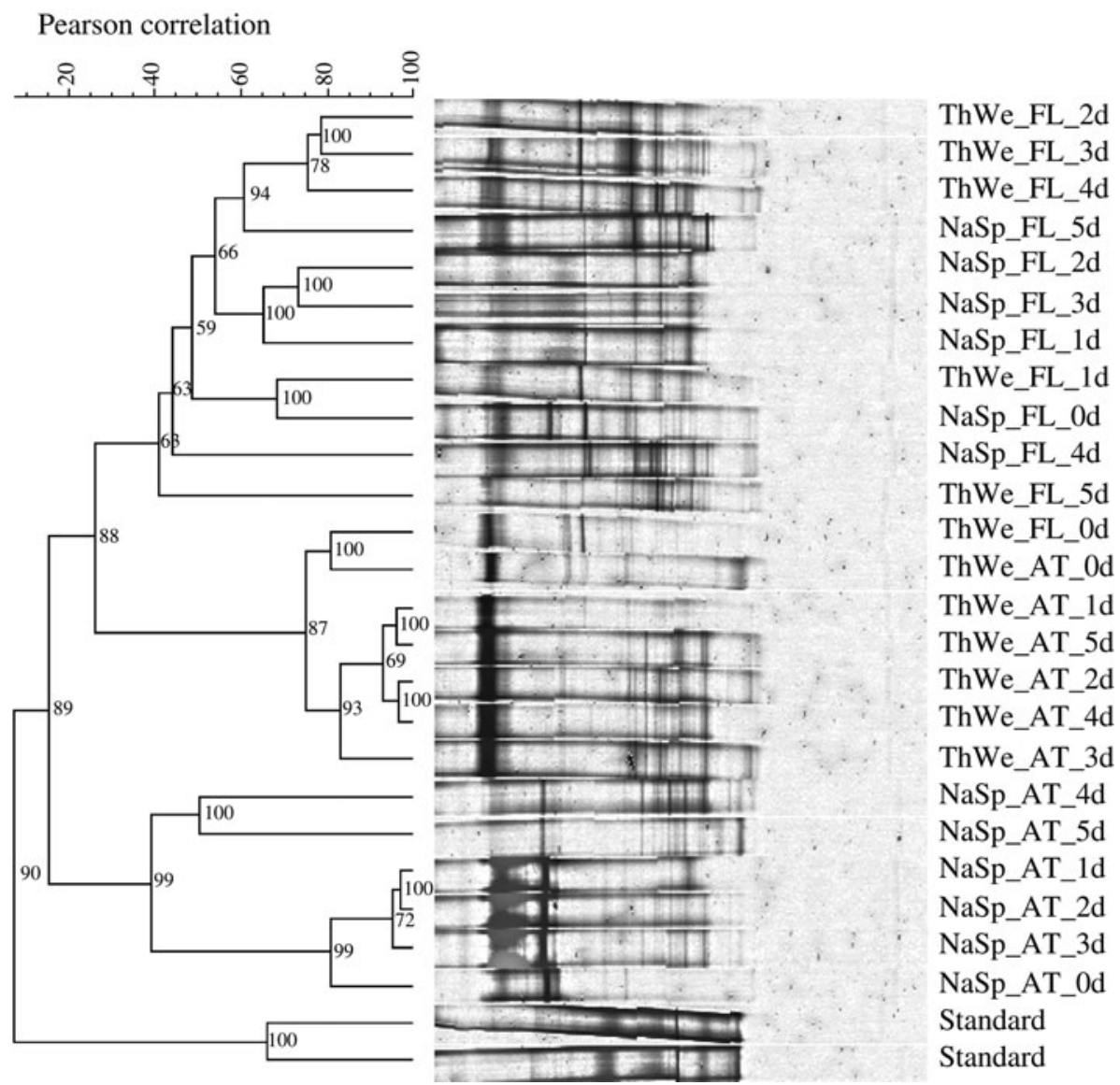

Fig. 3. Diatom culture experiments with non-axenic Thalassiosira weissflogii (ThWe) and Navicula sp. (NaSp). Cluster analysis of DGGE banding patterns of free-living (FL) and attached bacteria (AT) over a 5 d incubation period. Samples on Day 0 were taken after $12 \mathrm{~h}$ of inoculating the axenic algal cultures with natural seawater bacteria

\section{Bacterial colonization and detachment}

Bacteria from the ambient water of both algal cultures colonized agar spheres on Days 1 and 2 in a similar manner as previously described by Kiørboe et al. (2002). The number of attached cells increased at a decelerating rate towards a (temporary) steady state in which colonization was balanced by detachment (Fig. 4). The level of the steady states decreased for both cultures, with increasing incubation time indicating differences in the behaviour of the respective bacterial communities over time. The diffusivity of the bacteria and their specific detachment rates (Table 1) were estimated by fitting the model of Kiørboe et al. (2002) to the observations. There was a decline in bacterial diffusivity between Days 1 and 2 in both algal cultures. The difference between detachment and growth $(d-\mu)$, however, did not significantly change between Days 1 and 2 in Thalassiosira weissflogii cultures whereas it significantly increased in Navicula sp. cultures, indicating differ- ent bacterial behaviour in the 2 algal cultures. On Day 4 bacterial abundances did not saturate on our model particles within the observation period, suggesting that detachment was rapidly compensated by presumably bacterial growth since bacteria colonized the agar spheres at an overall lower rate on Day 4 than on Days 1 and 2.

Table 1. Estimates (mean $\pm \mathrm{SD}$ ) of bacterial diffusivities $(D)$ and differences between detachment and growth rates $(d-\mu)$ for bacteria from the phytoplankton cultures (see Fig. 4)

\begin{tabular}{|lccc|}
\hline $\begin{array}{l}\text { Phytoplankton } \\
\text { culture }\end{array}$ & Day & $\begin{array}{c}D \\
\left(10^{-5} \mathrm{~cm}^{2} \mathrm{~s}^{-1}\right)\end{array}$ & $\begin{array}{c}d-\mu \\
\left(10^{4} \mathrm{~s}^{-1}\right)\end{array}$ \\
\hline $\begin{array}{l}\text { Thalassiosira weissflogii } \\
\text { Thalassiosira weissflogii }\end{array}$ & 1 & $1.4 \pm 0.3$ & $1.4 \pm 0.5$ \\
Thalassiosira weissflogii & 4 & $0.4 \pm 0.1$ & $1.2 \pm 0.5$ \\
Navicula sp. & 1 & $2.1 \pm 0.4$ & - \\
Navicula sp. & 2 & $0.5 \pm 0.1$ & $1.2 \pm 0.6$ \\
Navicula sp. & 4 & - & - \\
& & & \\
\hline
\end{tabular}



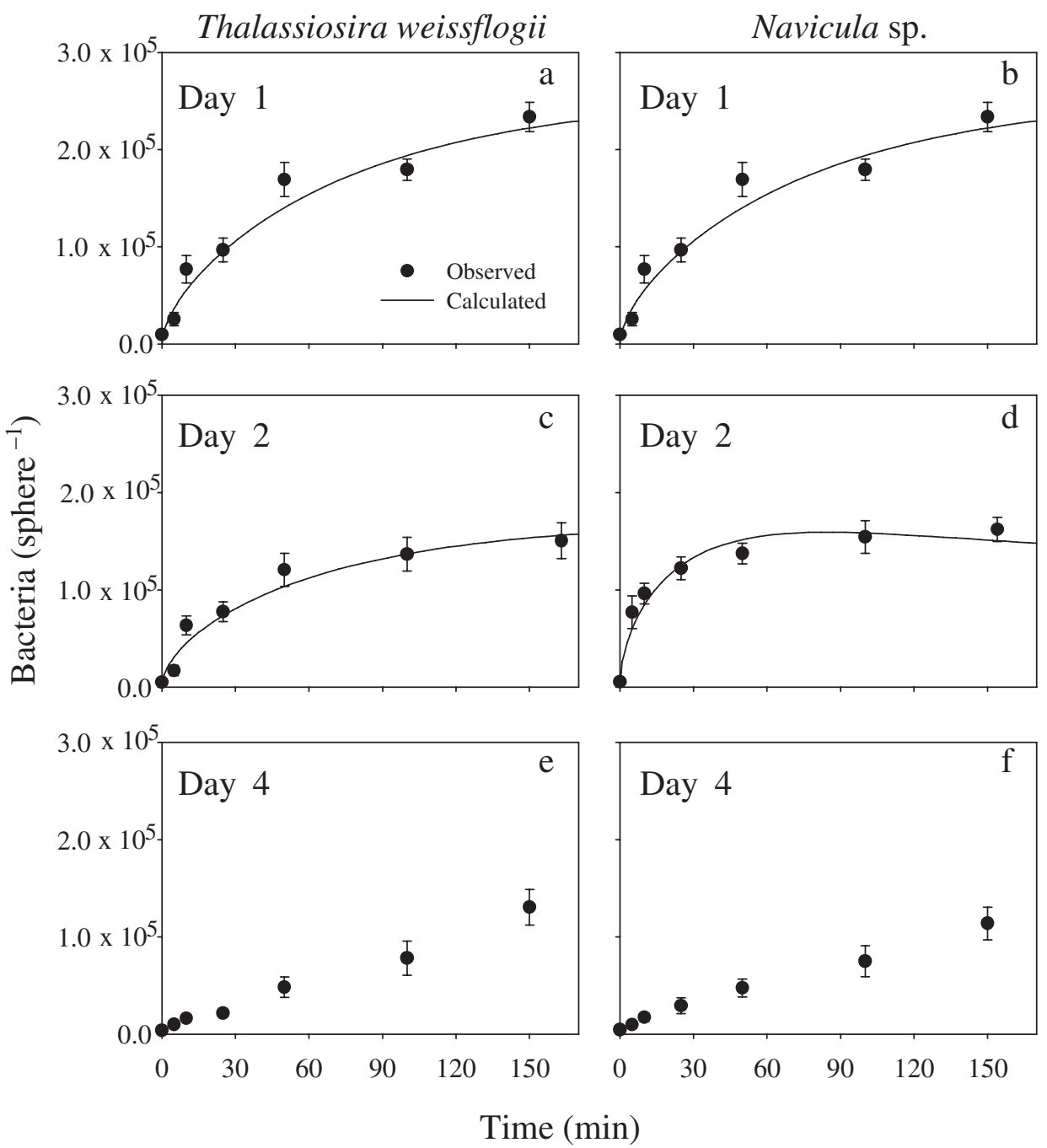

Fig. 4. Diatom culture experiments with $(\mathrm{a}, \mathrm{c}, \mathrm{e})$ non-axenic Thalassiosira weissflogii and $(\mathrm{b}, \mathrm{d}, \mathrm{f})$ Navicula sp. Colonization of agar spheres by ambient bacteria from the algal rolling bottles on Days 1,2, and 4 of the experiment. Lines are fits of the model of

Kiørboe et al. (2002, Eq. 8a). The model could not be fitted to experiments from Day 4 due to the lack of saturation

\section{DISCUSSION}

Heterotrophic bacteria are important for aggregation of phytoplankton cells, especially of marine diatoms (Simon et al. 2002 and references therein, Grossart et al. 2006). Previous studies (Deccho 1990, Griebe 1991, Heissenberger \& Herndl 1994) show that bacteria colonizing marine diatoms produce large amounts of exopolymeric substances, which increase phytoplankton cell stickiness and aggregation. A similar aggregation pattern has also been observed in rolling tank experiments with another diatom, Thalassiosira eccentrica (Griebe 1991). In our experiments we have only observed small amounts of exopolymeric material that was stained by either Alcian Blue or Coomassie Brilliant Blue, indicating that attached bacteria may produce different exopolymers (Böckelmann et al. 2002) and/or have other mechanisms to influence surface properties of the algal cells (Becker 1996, Stürmeyer et al. 1998). Epifluorescence microscopy revealed that bacteria often formed microcolonies embedded in an organic matrix that was slightly stained by DAPI but not by the histological dyes we used. We also observed that these microcolonies connected single algal cells with each other, thus forming aggregates.

In contrast to Thalassiosira weissflogii, cells of the diatom Navicula sp. secrete high amounts of exopolymeric substances (de Brouwer \& Stal 2002), which increases cell stickiness and aggregation even in the absence of bacteria (Passow \& Alldredge 1995). A similar pattern was observed for the marine diatom 
Skeletonema costatum (H. P. Grossart \& G. Czub unpubl.) and is also frequently observed during aggregation events of marine diatom blooms (Dam \& Drapeau 1995, Grossart et al. 2003a, Waite et al. 2005). Our microscopic studies revealed that the algal cells were increasingly colonized by heterotrophic bacteria, which accounted for a significant bacterial fraction at the end of the incubation. Even though attached bacteria are often characterized by extremely high rates of cell-specific protease activities and bacterial production rates (Smith et al. 1992, 1995, Grossart \& Simon 1998, this study), they did not seem to alter aggregation dynamics of Navicula sp. in our study. However, we observed that the axenic as well as non-axenic algal cells were embedded in a kind of exopolymer matrix that was stained neither by Alcian Blue nor Coomassie Brilliant Blue. By using the 2 algae with different aggregation patterns, it becomes clear that the role of heterotrophic bacteria for phytoplankton aggregation and vertical sinking flux can vary greatly among algal species. In natural and more diverse algal and bacterial communities different mechanisms may even exist at the same time.

There is still uncertainty as to whether free-living and particle-associated bacteria form distinct phylogenetic groups. Whereas Hollibaugh et al. (2000) did not find significant differences between free-living and attached bacteria, other authors demonstrate the presence of distinct compositions between the two fractions (DeLong et al. 1993, Bidle \& Fletcher 1995, Crump et al. 1999, Riemann et al. 2000, Grossart et al. 2005). In the present study, using diatom aggregates, we demonstrated a change in the marine snow bacterial community over time. Our experiments on colonization of agar spheres with bacteria from both algal experiments indicate that the rates of colonization significantly decreased throughout the incubation, suggesting that the population of 'particle specialists' in the ambient water decreased with time. These results were corroborated by the DGGE results, which showed that the attached bacteria were increasingly different phylogenetically from the free bacteria. Our findings imply that the presence of marine snow may induce a divergence of the ambient bacterial community to 2 distinct populations of 'particle specialists' that are increasingly associated with the aggregates, and 'free bacteria' that remain in suspension. Uncoupling between POM hydrolysis and subsequent uptake of hydrolysis products has been previously reported for attached bacteria and result in DOM release from marine aggregates (Smith et al. 1992, Grossart \& Simon 1998, Grossart \& Ploug 2001), which may stimulate the growth of even the surrounding free bacteria (Grossart \& Simon 1998, Kiørboe et al. 2001).
Bacterial abundance on marine snow particles is initially driven by a balance between bacterial attachment and detachment (Kiørboe et al. 2002), and subsequently by bacterial growth on the particle surfaces (Kiørboe et al. 2003). In the present study, percentages of attached bacteria greatly changed over time. In addition to bacterial colonization and growth, predation may also affect bacterial abundance and community composition on marine snow (e.g. Caron et al. 1982, Šimek et al. 2003). Microscopic observations revealed that when flagellates were present bacterial distribution tended to be patchy on the agar spheres, indicating a selection for grazing-resistant bacteria and their subsequent growth into patches.

In summary, the presence of heterotrophic bacteria can lead to dramatic changes in phytoplankton aggregation. In cultures of Thalassiosira weissflogii bacteria are a prerequisite for the formation of aggregates whereas in cultures of Navicula sp. bacteria seem to be of minor importance for algal aggregation. Varying roles of heterotrophic bacteria in phytoplankton aggregation can be explained by differences in algal exopolymer release, cell stickiness, and presumably bacterial community composition (Grossart et al. 2005). Through the interactions with algal aggregates and particles the bacterial community increasingly diverge into 2 specialized groups of bacteria: free-living and attached bacteria, which are highly restricted to their respective microenvironments. The development of these separate communities has profound implications for biogeochemical processes such as particle aggregation and degradation but also for trophic interactions.

Acknowledgements. We greatly appreciate the help of $\mathrm{K}$. Hutalle in performing PCR and DGGE analyses of the bacterial community composition. We thank E. Mach for technical assistance and the Leibniz Institute of Freshwater Ecology and Inland Fisheries for grants donated to H.P.G., T.K., K.W.T. and E.M.Y. T.K. was further supported by a grant from the Danish Natural Science Research Council (21-01-054) and K.W.T. and E.M.Y. by US NSF grant OCE-0352125. The use of Kristineberg Marine Research Station was supported by the EU Access to Research Infrastructure (ARI P.45).

\section{LITERATURE CITED}

Alldredge AL, Gotschalk CC (1990) The relative contribution of marine snow of different origins to biological processes in coastal waters. Cont Shelf Res 10:41-58

Azam F, Long RA (2001) Oceanography: sea snow microcosms. Nature 414:495-498

Becker K (1996) Exopolysaccharide production and attachment strength of bacteria and diatoms on substrates with different surface tensions. Microb Ecol 32:23-33

Bidle KD, Fletcher M (1995) Comparison of free-living and particle-associated bacterial communities in the Chesapeake Bay by stable low-molecular-weight RNA analysis. 
Appl Environ Microbiol 61:944-952

Böckelmann U, Manz W, Neu TR, Szewzyk U (2002) Investigation of lotic microbial aggregates by a combined technique of fluorescent in situ hybridization and lectinbinding-analysis. J Microbiol Methods 49:75-87

Brinkhoff T, Muyzer G (1997) Increased species diversity and extended habitat range of sulfur-oxidizing Thiomicrospira spp. Appl Environ Microbiol 63:3789-3796

Caron DA, Davis PG, Madin LP, Sieburth JMcN (1982) Heterotrophic bacteria and bacterivorous Protozoa in oceanic macroaggregates. Science 218:795-797

Crump BC, Armbrust EV, Baross JA (1999) Phylogenetic analysis of particle-attached and free-living bacterial communities in the Columbia river, its estuary, and the adjacent coastal ocean. Appl Environ Microbiol 65:3192-3204

Dam HG, Drapeau DT (1995) Coagulation efficiency, organicmatter glues and the dynamics of particles during a phytoplankton bloom in a mesocosm study. Deep-Sea Res II 42: 111-123

de Brouwer JFC, Stal LJ (2002) Daily fluctuations of exopolymers in cultures of the benthic diatoms Cylindrotheca closterium and Nitzschia sp (Bacillariophyceae). J Phycol 38:464-472

Decho AW (1990) Microbial exopolymer secretions in ocean environments: their role(s) in food webs and marine processes. Oceanogr Mar Biol Annu Rev 28:73-153

DeLong EF, Franks DG, Alldredge AL (1993) Phylogenetic diversity of aggregate-attached vs. free-living marine bacterial assemblages. Limnol Oceanogr 38:924-934

Eppley RW, Peterson BJ (1979) Particulate organic matter flux and planktonic new production in the deep ocean. Nature 282:677-680

Ferrari VC, Hollibaugh JT (1999) Distribution of microbial assemblages in the central Arctic Ocean basin studied by PCR/DGGE: analysis of a large data set. Hydrobiologia 401:55-68

Griebe T (1991) Experiments on aggregate formation. Diploma thesis, Institute of Hydrology and Fishery, University of Hamburg

Grossart HP, Ploug H (2001) Microbial degradation of organic carbon and nitrogen on diatom aggregates. Limnol Oceanogr 46:267-277

Grossart HP, Simon M (1998) Bacterial colonization and microbial decomposition of limnetic organic aggregates (lake snow). Aquat Microb Ecol 15:127-140

Grossart HP, Hietanen S, Ploug H (2003a) Microbial dynamics on diatom aggregates in Øresund, Denmark. Mar Ecol Prog Ser 249:69-78

Grossart HP, Kiørboe T, Tang K, Ploug H (2003b) Bacterial colonization of marine particles: growth and inter-specific interactions. Appl Environ Microbiol 69:3500-3509

Grossart HP, Levold F, Allgaier M, Simon M, Brinkhoff T (2005) Marine diatom species harbour distinct bacterial communities. Environ Microbiol 7:860-873

Grossart HP, Czub G, Simon M (2006) Specific interactions of planktonic algae and bacteria: a key for understanding organic matter cycling and aggregation processes in the sea. Environ Microbiol (in press)

Editorial responsibility: Karel Šimek,

České Budějovice, Czech Republic
Heissenberger A, Herndl GJ (1994) Formation of high molecular weight material by free-living marine bacteria. Mar Ecol Prog Ser 111:129-135

Hollibaugh JT, Wong PS, Murrell MC (2000) Similarity of particle-associated and free-living bacterial communities in northern San Francisco Bay, California. Aquat Microb Ecol 21:103-114

Kiørboe T, Ploug H, Thygesen UH (2001) Fluid motion and solute distribution around sinking aggregates. I. Smallscale fluxes and heterogeneity of nutrients in the pelagic environment. Mar Ecol Prog Ser 211:1-13

Kiørboe T, Grossart HP, Ploug H, Tang K (2002) Mechanisms and rates of bacterial colonization of sinking aggregates. Appl Environ Microbiol 68:3996-4006

Kiørboe T, Tang K, Grossart HP, Ploug H (2003) Dynamics of microbial communities on marine snow aggregates: colonization, growth, detachment and grazing mortality of attached bacteria. Appl Environ Microbiol 69:3036-3047

Kirchman DL (2002) The ecology of Cytophaga-Flavobacteria in aquatic environments. FEMS Microbiol Ecol 39:91-100

Logan BE, Grossart HP, Simon M (1994) Direct observation of phytoplankton, TEP and aggregates on polycarbonate filters using brightfield microscopy. J Plankton Res 16: 1811-1815

Long RA, Azam F (1996) Abundant protein-containing particles in the sea. Aquat Microb Ecol 10:213-221

Passow U, Alldredge AL (1995) Aggregation of a diatom bloom in a mesocosm - the role of transparent exopolymer particles (TEP). Deep-Sea Res II 42:99-109

Riemann L, Steward GF, Azam F (2000) Dynamics of bacterial community composition and activity during a mesocosm diatom bloom. Appl Environ Microbiol 66:578-587

Šimek K, Hornak K, Masin M, Christaki U, Nedoma J, Weinbauer MG, Dolan JR (2003) Comparing the effects of resource enrichment and grazing on a bacterioplankton community of a meso-eutrophic reservoir. Aquat Microb Ecol 31:123-135

Simon M, Grossart HP, Schweitzer B, Ploug H (2002) Microbial ecology of organic aggregates in aquatic ecosystems. Aquat Microb Ecol 28:175-211

Smith DC, Simon M, Alldredge AL, Azam F (1992) Intense hydrolytic enzyme activity on marine aggregates and implications for rapid particle dissolution. Nature 329: 139-142

Smith DC, Steward GF, Long RA, Azam F (1995) Bacterial mediation of carbon fluxes during a diatom bloom in a mesocosm. Deep-Sea Res II 42:75-97

Stürmeyer $\mathrm{H}$, Overmann J, Babenzien HD, Cypionka $\mathrm{H}$ (1998) Ecophysiological and phylogenetic studies of Nevskia ramosa in pure culture. Appl Environ Microbiol 64:1890-1894

Waite AM, Gustafsson Ö, Lindahl O, Tiselius P (2005) Linking ecosystem dynamics and biogeochemistry: sinking fractionation of organic carbon in a Swedish fjord. Limnol Oceanogr 50:658-671

Zhou J, Bruns MA, Tiedje JM (1996) DNA recovery from soils of diverse composition. Appl Environ Microbiol 62: $695-724$

Submitted: September 12, 2005; Accepted: November 29, 2005 Proofs received from author(s): January 27, 2006 